Pacific Northwest National Laboratory

Operated by Battelle for the U.S. Department of Energy
RECEIVED NOV 101998

OSTI

\title{
Radionuclide Incorporation in Secondary Crystalline Minerals Resulting from Chemical Weathering of Selected Waste Glasses: Progress Report for Subtask 3d
}
S. V. Mattigod
R. D. Orr
D. I. Kaplan
H. T. Schaef
V. L. LeGore
J. S. Young

October 1998

Prepared for the U.S. Department of Energy under Contract DE-AC06-76RLO 1830 


\title{
DISCLAIMER
}

This report was prepared as an account of work sponsored by an agency of the United States Government. Neither the United States Government nor any agency thereof, nor Battelle Memorial Institute, nor any of their employees, makes any warranty, express or implied, or assumes any legal liability or responsibility for the accuracy, completeness, or usefulness of any information, apparatus, product, or process disclosed, or represents that its use would not infringe privately owned rights, Reference herein to any specific commercial product, process, or service by trade name, trademark, manufacturer, or otherwise does not necessarily constitute or imply its endorsement, recommendation, or favoring by the United States Government or any agency thereof, or Battelle Memorial Institute. The views and opinions of authors expressed herein do not necessarily state or reflect those of the United States Government or any agency thereof.

\author{
PACIFIC NORTHWEST NATIONAL LABORATORY \\ operated by \\ BATTELLE \\ for the \\ UNITED STATES DEPARTMENT OF ENERGY \\ under Contract DE-AC06-76RLO 1830
}

\author{
Printed in the United States of America \\ Available to DOE and DOE contractors from the \\ Office of Scientific and Technical Information,P.O. Box 62, Oak Ridge, TN 37831; \\ prices available from (615) 576-8401. \\ Available to the public from the National Technical Information Service, \\ U.S. Department of Commerce, 5285 Port Royal Rd,, Springfield, VA 22161
}




\section{DISCLAIMER}

\section{Portions of this document may be illegible in electronic image products. Images are produced from the best available original document.}




\section{Radionuclide Incorporation in Secondary Crystalline Minerals Resulting from Chemical Weathering of Selected Waste Glasses: Progress Report for Subtask 3d}
S. V. Mattigod
R. D. Orr
D. I. Kaplan
H. T. Schaef
V. L. LeGore
J. S. Young

October 1998

Prepared for

the U.S. Department of Energy

under Contract DE-AC06-76RLO 1830

Pacific Northwest National Laboratory

Richland, Washington 99352 



\section{Summary}

Experiments were conducted in fiscal year 1998 by Pacific Northwest National Laboratory ${ }^{1}$ to evaluate potential incorporation of radionuclides in secondary mineral phases that form from weathering vitrified nuclear waste glasses. These experiments were conducted as part of the Immobilized LowActivity Waste-Performance Assessment (ILAW-PA) to generate data on radionuclide mobilization and transport in a near-field environment of disposed vitrified wastes.

An initial experiment was conducted to identify the types of secondary minerals that form from two glass samples of differing compositions, LD6 and SRL202. Chemical weathering of LD6 glass at $90^{\circ} \mathrm{C}$ in contact with an aliquot of uncontaminated Hanford Site groundwater resulted in the formation of a crystalline zeolitic mineral, phillipsite. In contrast, similar chemical weathering of SRL202 glass at $90^{\circ} \mathrm{C}$ resulted in the formation of a microcrystalline smectitic mineral, nontronite.

A second experiment was conducted at $90^{\circ} \mathrm{C}$ to assess the degree to which key radionuclides would be sequestered in the structure of secondary crystalline minerals; namely, phillipsite and nontronite. Chemical weathering of LD6 in contact with radionuclide-spiked Hanford Site groundwater indicated that substantial fractions of the total activities were retained in the phillipsite structure.

Similar chemical weathering of SRL202 at $90^{\circ} \mathrm{C}$, also in contact with radionuclide-spiked Hanford Site groundwater, showed that significant fractions of the total activities were retained in the nontronite structure.

These results have important implications regarding the radionuclide mobilization aspects of the ILAW-PA. Additional studies are required to confirm the results and to develop an improved understanding of mechanisms of sequestration and attenuated release of radionuclides to help refine certain aspects of their mobilization.

\footnotetext{
${ }^{1}$ Pacific Northwest National Laboratory is operated by Battelle for the U.S. Department of Energy.
} 



\section{Acknowledgments}

The authors thank Frederick Mann of Fluor Daniel Northwest, Inc. for consistent support and encouragement. We thank J. R. Rustad for providing the crystal structure diagrams, B. V. Johnston for editorial assistance, and K. R. Neiderhiser for text processing. We also thank R. J. Serne and B. P. McGrail for reviewing this report and providing valuable suggestions. 



\section{Contents}

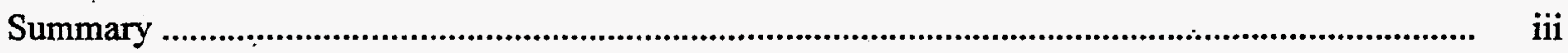

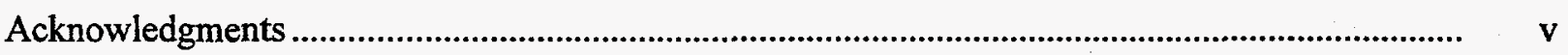

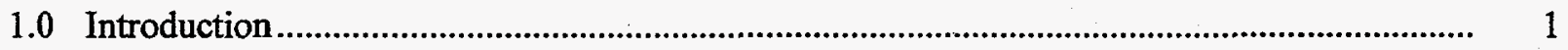

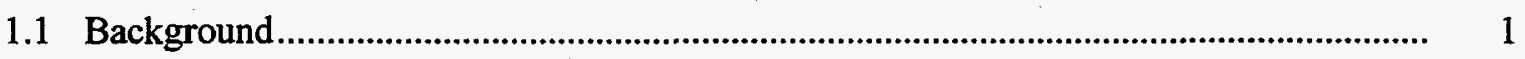

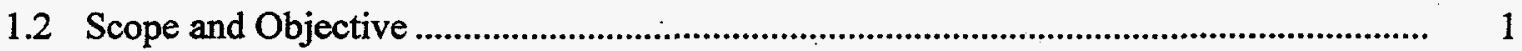

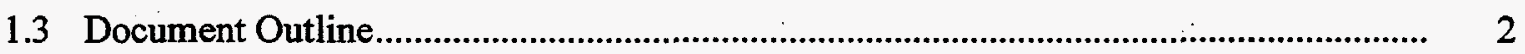

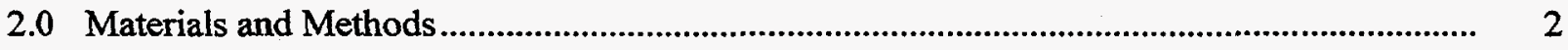

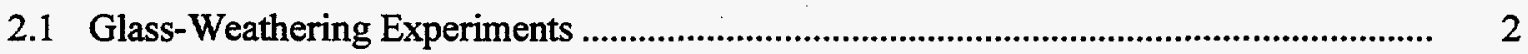

2.2 Radionuclide Sequestration Experiments ..................................................................... 4

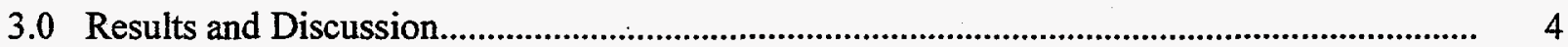

3.1 Glass-Weathering Experiments ........................................................................................ 4

3.1.1 Weathering Products of LD6 Glass ....................................................................... 4

3.1.2 Weathering Products of SRL202 Glass ........................................................... 10

3.2 Radionuclide Sequestration Experiments ................................................................ 15

3.2.1 Radionuclide Substitutions in Phillipsite Phase..................................................... 15

3.2.2 Radionuclide Substitutions in Nontronite Phase.................................................... 16

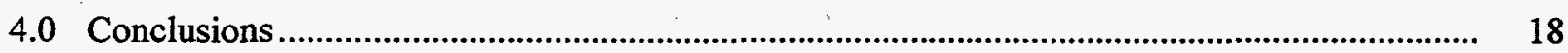

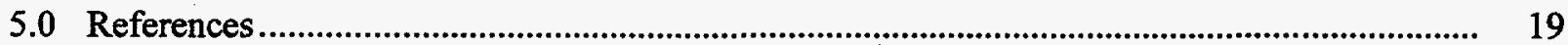




\section{Figures}

1 X-Ray Diffraction Data for Crystalline Secondary Phases Formed from Weathered LD6 Glass

2 Schematic Structural Diagram of Phillipsite ........................................................................

3 Scanning Electron Micrograph of Fresh LD6 Glass Particles ............................................. 8

4 Scanning Electron Micrograph of Clusters of Prismatic Phillipsite Crystals Formed

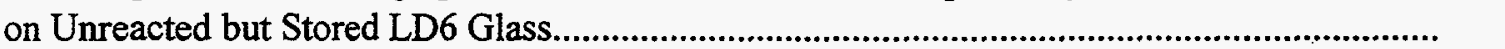

5 Scanning Electron Micrograph of Clusters of Prismatic Phillipsite Crystals Formed from Weathered LD6 Glass Particles.................................................................................... 9

6 Higher Magnification Scanning Electron Micrograph of Phillipsite Crystals .......................... 9

7 X-Ray Diffraction Data for Crystalline Secondary Phases Formed from Weathered SRL202 Glass

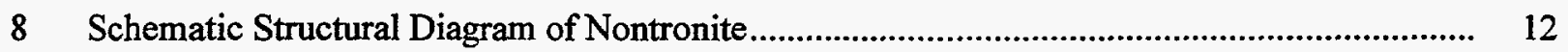

9 Scanning Electron Micrograph of Fresh SRL202 Glass Particles .....................................

10 Scanning Electron Micrograph of Agglomerated Sheets of Nontronite Crystals

Formed from Weathered SRL202 Glass Particles

11 Higher Magnification Scanning Electron Micrograph of Nontronite Crystals

\section{Tables}

1 Chemical Composition of LD6 and SRL202 Glasses ..................................................... 3

2 Chemical Composition of Uncontaminated Hanford Site Groundwater.................................. 3

3 Analysis of Phillipsite Crystals Formed from LD6 Glass .............................................. 10

$4 \quad$ Analysis of Nontronite Crystals Formed from SRL202 Glass......................................... 14 
$5 \quad$ Radionuclide Fractions Associated with Phillipsite Mineral .............................................. 15

6 Evaluation Matrix for Radionuclide Incorporation in Phillipsite Structure ............................. 16

$7 \quad$ Radionuclide Fractions Associated with Nontronite Mineral ............................................... 16

$8 \quad$ Evaluation Matrix for Radionuclide Incorporation in Nontronite Structure ........................... 17 


\subsection{Introduction}

A performance assessment (PA) is under way to evaluate the suitability of the unsaturated sediments at the Hanford Site for the long-term disposal of vitrified low-activity waste. This assessment consists of analyses that predict the transport of radionuclides and/or contaminants from a source to a receptor via pathways that are considered credible. Previous analyses for proposed disposal actions on the Hanford Site show that groundwater transport presents the greatest potential for long-term dose uptake by humans (Mann et al. 1998). Furthermore, these previous analyses have shown that the key risk drivers at the proposed disposal site include ${ }^{79} \mathrm{Se},{ }^{99} \mathrm{Tc},{ }^{129} \mathrm{I},{ }^{233,235,238} \mathrm{U}$, and ${ }^{237} \mathrm{~Np}$.

\subsection{Background}

Currently, data are lacking on the tendency of key radionuclides to be sequestered into secondary crystalline mineral structures. This lack of knowledge could adversely affect waste-disposal activities by increasing the uncertainty and requiring unrealistically conservative estimates be used as inputs to dose calculations.

It is expected that the leachate from the glass waste forms and concrete vaults used to dispose of the immobilized low-activity waste (ILAW) will have very high ionic strengths (very high concentrations of

dissolved constituents) and will be extremely alkaline (very high $\mathrm{pH}$ ) in nature (Mann et al. 1998). Under such extreme conditions, several complex geochemical reactions are known to occur in waste forms, neighboring engineered structures, and surrounding sediments that include dissolution of several carbonate and silicate minerals, precipitation of secondary and tertiary mineral phases, radionuclide adsorption onto minerals (primary, secondary, and tertiary), and sequestration of radionuclides into secondary and tertiary mineral phases. Several studies of waste and volcanic glasses and grouts have shown that formation of zeolitic and smectitic secondary crystalline minerals as a product of chemical weathering is a very common phenomena (Collella et al. 1978; Holler and Wirsching 1978; Van Iseghem et al. 1985; Van Iseghem and Grambow 1988; Haaker et al. 1985; Lutze et al. 1988; Caurel et al. 1988; McGrail et al. 1997a, 1997b, 1998; Ebert and Tam 1997; Luo et al. 1997; Fortner et al. 1997). Extensive reviews by Barrer (1982) and Newman and Brown (1987) of literature on isomorphous substitution in zeolites and smectites suggest that radionuclides in waste forms could, on chemical weathering, be sequestered in these secondary crystalline mineral structures. Because zeolites and smectites have significantly lower solubilities than glass waste forms, the aqueous-phase activities (concentrations) of isomorphically substituted radionuclides would be significantly decreased.

\subsection{Scope and Objective}

This study consisted of two experiments. The initial experiment was conducted to identify and characterize the type of secondary minerals that form from chemical weathering of two waste glass samples of differing composition in contact with uncontaminated Hanford Site groundwater. The second 
experiment was conducted to assess the degree to which key radionuclides would be incorporated into secondary mineral phases that form from weathering glasses. The objective of this study was to determine the potential sequestration of some of the key radionuclides $\left({ }^{79} \mathrm{Se},{ }^{99} \mathrm{Tc},{ }^{129} \mathrm{I}\right.$, and $\left.{ }^{233,235,238} \mathrm{U}\right)$ in secondary crystalline minerals that form as products of chemical weathering of vitreous waste forms.

\subsection{Document Outline}

This document consists of four chapters. This introduction is followed by a discussion of the materials and methods used in the two experiments. The results and discussions of the glass-weathering and radionuclide sequestration experiments are given in Chapter 3.0. The conclusions gathered from the experiments are presented in Chapter 4.0, followed by the references cited in the text in Chapter 5.0.

\subsection{Materials and Methods}

\subsection{Glass-Weathering Experiments}

Each glass-weathering experiment was set up to periodically monitor the formation of secondary crystalline minerals. Because the objectives of this experiment were to identify and characterize the type of secondary minerals, no radionuclides were introduced to the glasses.

Two glasses of different compositions were used in these experiments (Table 1). The reasons for selecting these two glasses were that their physical and chemical characteristics have been wellestablished and their compositions differ significantly and, therefore, likely lead to different weathering products. The LD6 glass is a sodium aluminosilicate glass with minor amounts of calcium, potassium, and boron (McGrail et al. 1997a). In contrast, SRL202 glass is an alkali (lithium, sodium, and potassium) iron borosilicate glass with minor amounts of calcium, magnesium, aluminum, manganese, nickel, and zirconium (Ebert and Tam 1997). The glasses were prepared for the weathering experiments by crushing and grinding the material to pass through a $\# 325$ sieve $(<44 \mu \mathrm{m})$.

The groundwater used in these experiments was collected from well 699-S3-25, located on the Hanford Site (Table 2). The composition of the groundwater indicates that calcium, magnesium, sodium, and potassium are the principal cationic constituents, with chloride, sulfate, and carbonate the dominant anions. The charge-balance calculations $(+5 \%)$ indicated that the chemical analysis of this water is complete and accurate.

The weathering experiment was conducted by weighing 5 -g portions of each glass into 4 Teflon ${ }^{\mathrm{TM}}$ Parr bomb containers (Parr Instruments, Moline, Illinois). Hanford Site groundwater ( $5 \mathrm{~mL}$ ) was added to the glass samples, the containers were sealed, and then placed in an oven preheated to $90^{\circ} \mathrm{C}$. At the end of every week, for a period of 4 weeks, a sample of each weathered glass was removed from the oven and 
Table 1. Chemical Composition of LD6 and SRL202 Glasses

\begin{tabular}{|c|c|c|}
\hline Element (Oxide Basis) & $\begin{array}{l}\text { LD6 }{ }^{(a)} \\
(w t \%)\end{array}$ & $\begin{array}{l}\text { SRL202 } \\
(w t \%)\end{array}$ \\
\hline $\mathrm{Al}_{2} \mathrm{O}_{3}$ & 12.00 & 3.84 \\
\hline $\mathrm{B}_{2} \mathrm{O}_{3}$ & 5.00 & 7.97 \\
\hline $\mathrm{CaO}$ & 4.00 & 1.20 \\
\hline $\mathrm{Fe}_{2} \mathrm{O}_{3}$ & - & 11.40 \\
\hline $\mathrm{K}_{2} \mathrm{O}$ & 1.46 & 3.71 \\
\hline $\mathrm{Li}_{2} \mathrm{O}$ & - & 4.23 \\
\hline $\mathrm{MgO}$ & - & 1.23 \\
\hline $\mathrm{MnO}_{2}$ & -- & 2.21 \\
\hline $\mathrm{Na}_{2} \mathrm{O}$ & 20.00 & 8.92 \\
\hline $\mathrm{NiO}$ & -- & 0.82 \\
\hline $\mathrm{SiO}_{2}$ & 55.91 & 48.90 \\
\hline $\mathrm{ZrO}_{2}$ & -- & 0.10 \\
\hline \multicolumn{3}{|c|}{$\begin{array}{l}\text { (a) McGrail et al. (1997). } \\
\text { (b) Ebert and Tam (1997). }\end{array}$} \\
\hline
\end{tabular}

Table 2. Chemical Composition of Uncontaminated Hanford Site Groundwater $(0.45 \mu \mathrm{m}$ filtered $)$

\begin{tabular}{|l|c|}
\hline \multicolumn{1}{|c|}{ Constituent } & Concentration (mmol/L) \\
\hline \hline $\mathrm{pH}$ & 8.4 (unitless) \\
\hline $\mathrm{Cl}$ & 0.677 \\
\hline $\mathrm{NO}_{3}$ & 0.027 \\
\hline $\mathrm{SO}_{4}$ & 1.135 \\
\hline $\mathrm{C}$ (organic) & 0.061 \\
\hline $\mathrm{CO}_{3}$ & 2.623 \\
\hline $\mathrm{Al}$ & 0.005 \\
\hline $\mathrm{B}$ & 0.005 \\
\hline $\mathrm{Ba}$ & 0.001 \\
\hline $\mathrm{Ca}$ & 1.447 \\
\hline $\mathrm{Fe}$ & 0.003 \\
\hline $\mathrm{K}$ & 0.358 \\
\hline $\mathrm{Mg}$ & 0.658 \\
\hline $\mathrm{Mn}$ & 0.001 \\
\hline $\mathrm{Na}$ & 1.305 \\
\hline $\mathrm{Si}$ & 0.577 \\
\hline
\end{tabular}


cooled. The solids were gently crushed; washed with deionized, distilled water; air dried; and characterized using X-ray diffraction (XRD) analysis. The glass samples weathered 4 weeks in addition to mineralogical characterization were also morphologically and chemically characterized by using scanning electron microscopy coupled to an energy dispersive X-ray spectrometer (SEM-EDS).

The weathered glass samples were prepared for XRD analysis by packing subsamples into aluminum

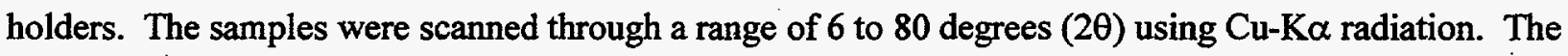
diffraction data were analyzed by using software linked to an international diffraction database. For SEM-EDS analysis, milligram-sized subsamples of fresh and weathered (4-week) glasses were mounted on carbon specimen stubs and vacuum coated with a conducting carbon film. Spot analyses of fresh glass surfaces and secondary crystalline minerals were conducted, and the spectral data were processed by the instrumental software to obtain semiquantitative chemical analysis.

\subsection{Radionuclide Sequestration Experiments}

Five-g portions of each glass were transferred into 4 Teflon Parr bomb containers. Individual 5-mL aliquots of Hanford Site groundwater were spiked separately with either ${ }^{75} \mathrm{Se},{ }^{99} \mathrm{Tc},{ }^{125} \mathrm{I}$, or ${ }^{238} \mathrm{U}$ and these individually spiked aliquots were added to one of the 4 sample containers of each glass. The spike levels ranged from 40 to $120 \mathrm{nCi}$. For control, $5-\mathrm{mL}$ aliquots of similarly spiked groundwater were transferred to 4 blank containers. All containers were sealed and placed in an oven preheated to $90^{\circ} \mathrm{C}$. At the end of 4 weeks, the weathered glass samples were removed from the oven and cooled. The samples were crushed and washed three times with deionized, distilled water. The wash water was composited and successively filtered through $0.45-\mu \mathrm{m}$ and Amicon $(20 \AA)$ filters and the activities of ${ }^{99} \mathrm{Tc}$ and ${ }^{238} \mathrm{U}$ in the filtrates were counted (Amicon is a subdivision of Millipore Corporation, Bedford, Massachusetts). The solids were air dried, and the activities of ${ }^{75} \mathrm{Se}$ and ${ }^{125} \mathrm{I}$ in the solid phase were determined. The activities of ${ }^{99} \mathrm{Tc}$ and ${ }^{238} \mathrm{U}$ in the liquid samples were determined by liquid scintillation counting (LSC), using a quench-calibrated Wallac $\left(1415\right.$ and Packard $\odot$ Optifluor ${ }^{\mathrm{TM}}$ LSC cocktail (Wallic Instruments, Inc. and Packard Instruments, Meriden, Connecticut). Analysis of ${ }^{75} \mathrm{Se}$ and ${ }^{125} \mathrm{I}$ in liquid and solid samples were conducted by gamma-ray spectrometry, using a calibrated Wallac $\circledast 1480$ Wizard $^{\mathrm{TM}} 3$-in. NaI detector with built-in software.

\subsection{Results and Discussion}

\subsection{Glass-Weathering Experiments}

\subsubsection{Weathering Products of LD6 Glass}

At the end of the second week of weathering, XRD-detectable quantities of a crystalline phase were present in the LD6 glass (Figure 1). Significant increases in diffraction intensities indicated that 


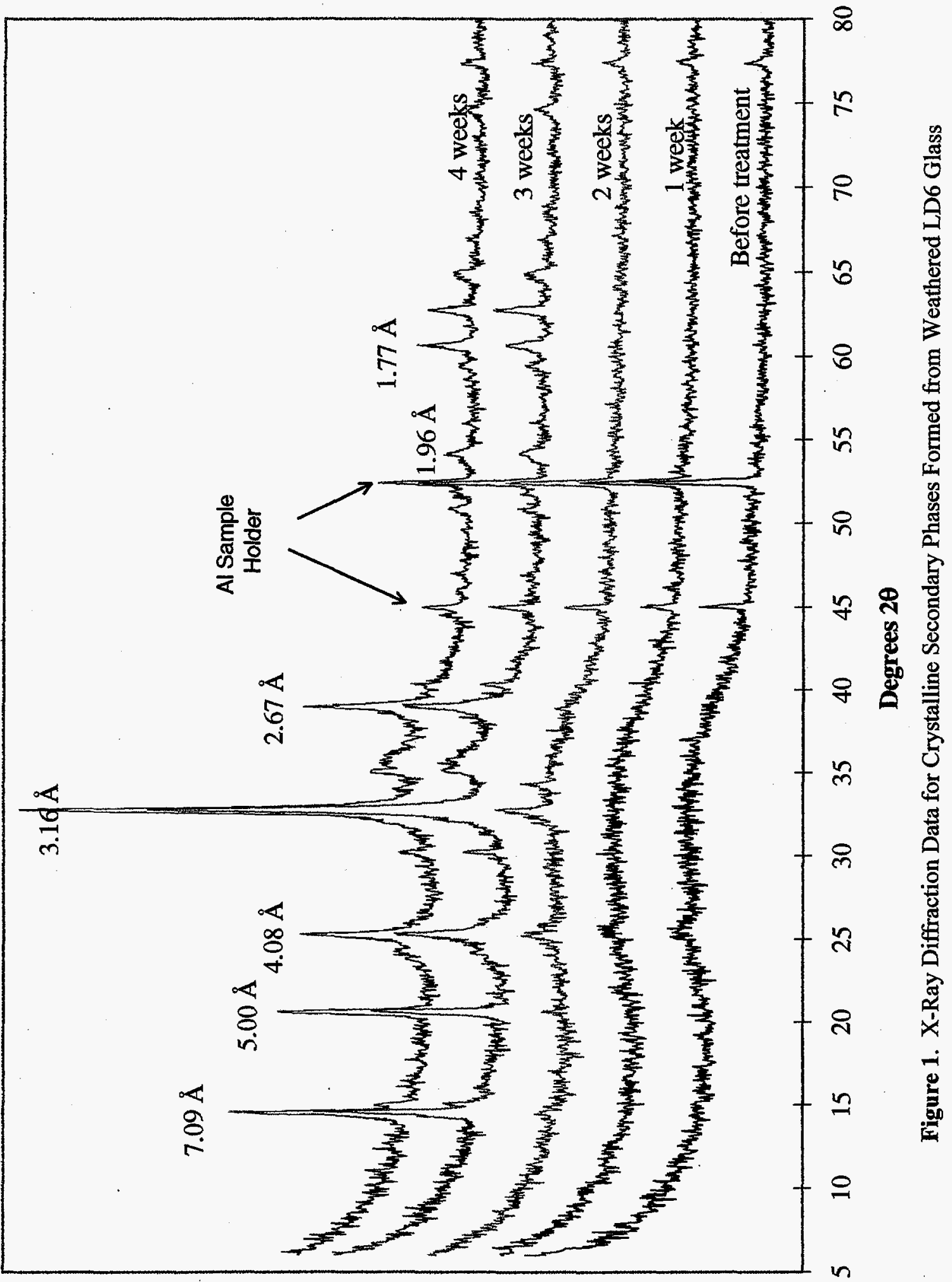


substantial quantities of glass had converted into crystalline material. No significant differences in diffraction peak intensities of samples between the third and fourth weeks of weathering were observed, indicating that formation of secondary crystalline phases was substantially complete by the end of the third week. The diffraction data from weathered LD6 glass matched the standard diffraction data for phillipsite, a zeolite mineral. Phillipsite is an aluminosilicate mineral with a doubly connected 4-ring framework structure and is known to form from weathering of alkali glasses and gels (Breck 1974, Barrer 1982, Gottardi and Galli 1985). The framework consists of tetrahedrally coordinated Si and Al that form 8-ringed channels in both $a$ and $b$ crystallographic directions (Breck 1974). These open channels, with dimensions of $4.2 \times 4.8 \AA$ and $2.8 \times 4.8 \AA$, contain hydrated exchangeable cations that are coordinated with framework oxygen. These exchangeable cations compensate the positive charge deficiency in the structure arising from the lower valence ion, Al(III) substituting for the higher valence ion, Si(IV). A schematic of the phillipsite structure, consisting of a tetrahedrally coordinated framework and an 8-ring channel, is shown in Figure 2.

Scanning electron micrographs of unreacted LD6 glass showed glass particles of $\sim 50-\mu \mathrm{m}$ average size, with typical conchoidally fractured surfaces and clear, smooth surfaces covered with smaller glass particles (Figure 3). SEM observations also showed that some of the glass particles before being reacted at $90^{\circ} \mathrm{C}$ had overgrowths of phillipsite crystals (Figure 4). The presence of phillipsite, a secondary mineral in fresh glass, indicated that the glass surfaces were highly reactive and that some of these particles during storage at room temperature appeared to have reacted with ambient moisture, resulting in clusters of phillipsite. Such formation of phillipsite under ambient conditions is in accordance with observations of this mineral's formation under earth-surface conditions (Gottardi and Galli 1985).

As expected, SEM examination of glass particles weathered for 4 weeks revealed dense, radiating clusters of prismatic crystals of phillipsite growing on matrices of highly weathered (corroded) glass (Figure 5). A highly magnified view of a cluster (Figure 6) indicated that these prismatic crystals were $\sim 2$ to $5 \mu \mathrm{m}$ in length, with widths ranging from 0.25 to $0.5 \mu \mathrm{m}$. The appearance of these clusters of phillipsite crystals is morphologically similar to phillipsites formed from weathering volcanic glasses (as illustrated by Gottardi and Galli 1985).

The chemical composition of phillipsite crystals was measured using EDS. The elemental concentrations expressed on an oxide basis (Table 3 ) indicated that phillipsite, which forms from weathering LD6 glass, is similar in composition to some silica- and sodium-rich phillipsites derived from weathered volcanic glasses. Based on the geochemical factor that aluminum is a conservative element (practically all aluminum in the weathering mineral is transferred into secondary mineral phases), an average unit cell formula for phillipsite was calculated as

$$
\left(\mathrm{Na}_{3.4} \mathrm{~K}_{0.6}\right)\left(\mathrm{Al}_{4} \mathrm{Si}_{16}\right) \mathrm{O}_{20} \cdot 12 \mathrm{H}_{2} \mathrm{O}
$$

The LD6 glass-derived phillipsite appears to have $\sim 80 \%$ of the tetrahedral sites filled with silicon and $\sim 85 \%$ of the cation-exchange sites filled with sodium (calculated cation-exchange capacity of $\sim 2.6 \mathrm{meq} / \mathrm{g}$ ). 


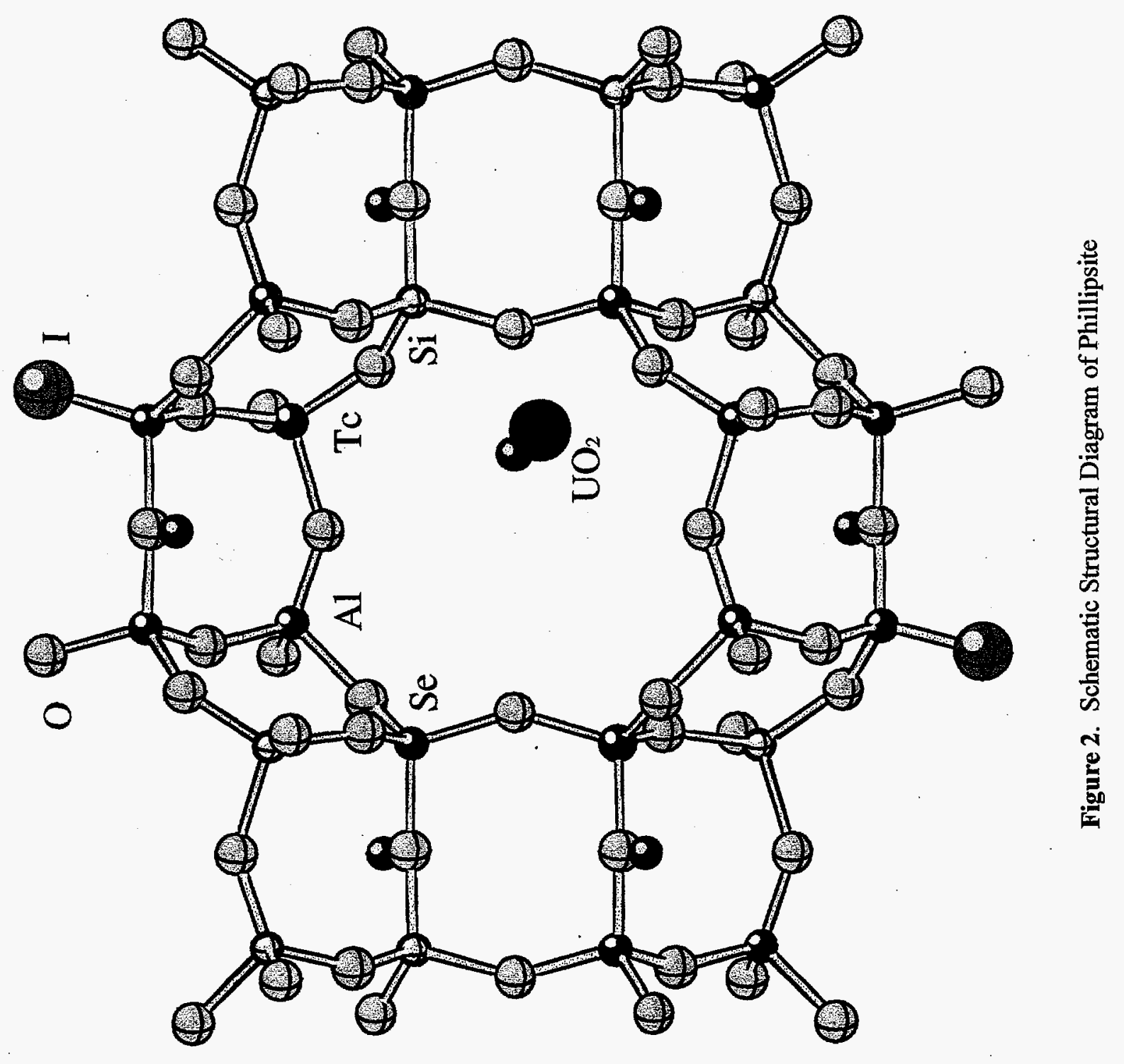




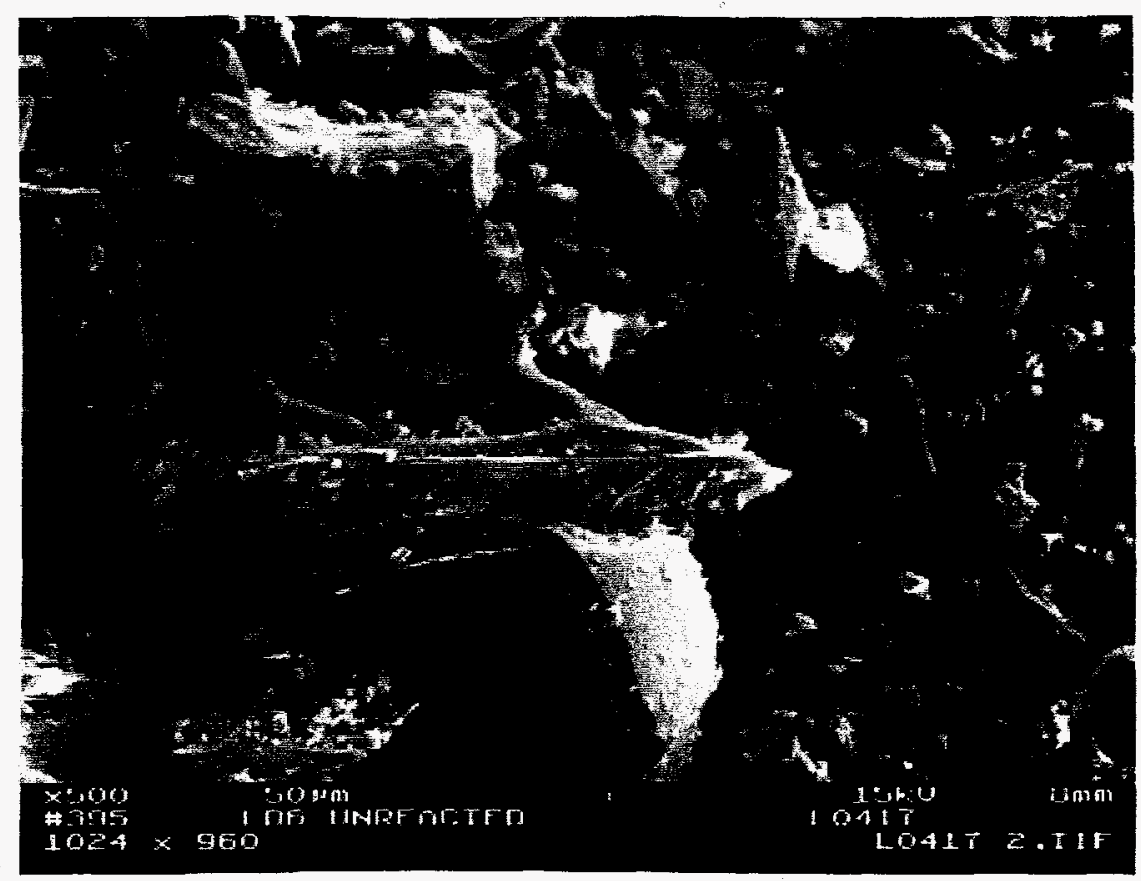

Figure 3. Scanning Electron Micrograph of Fresh LD6 Glass Particles

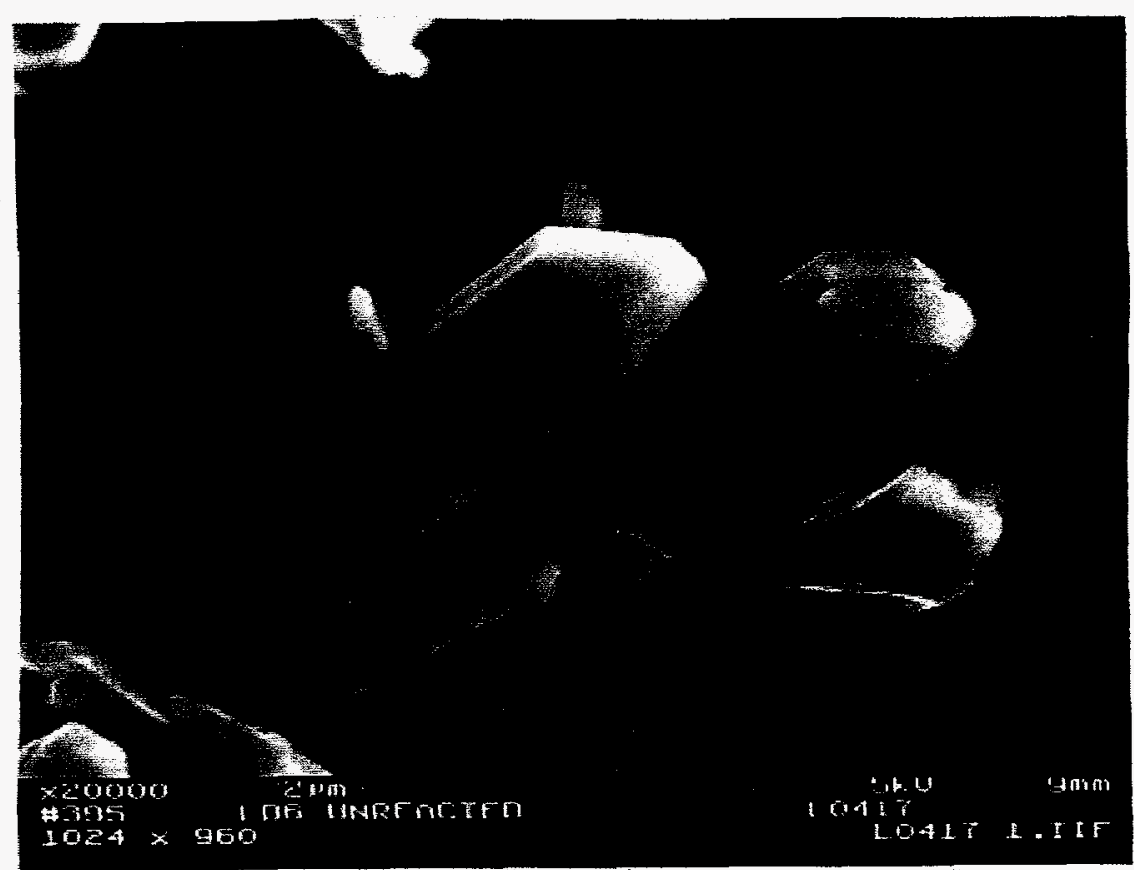

Figure 4. Scanning Electron Micrograph of Clusters of Prismatic Phillipsite Crystals Formed on Unreacted but Stored LD6 Glass 


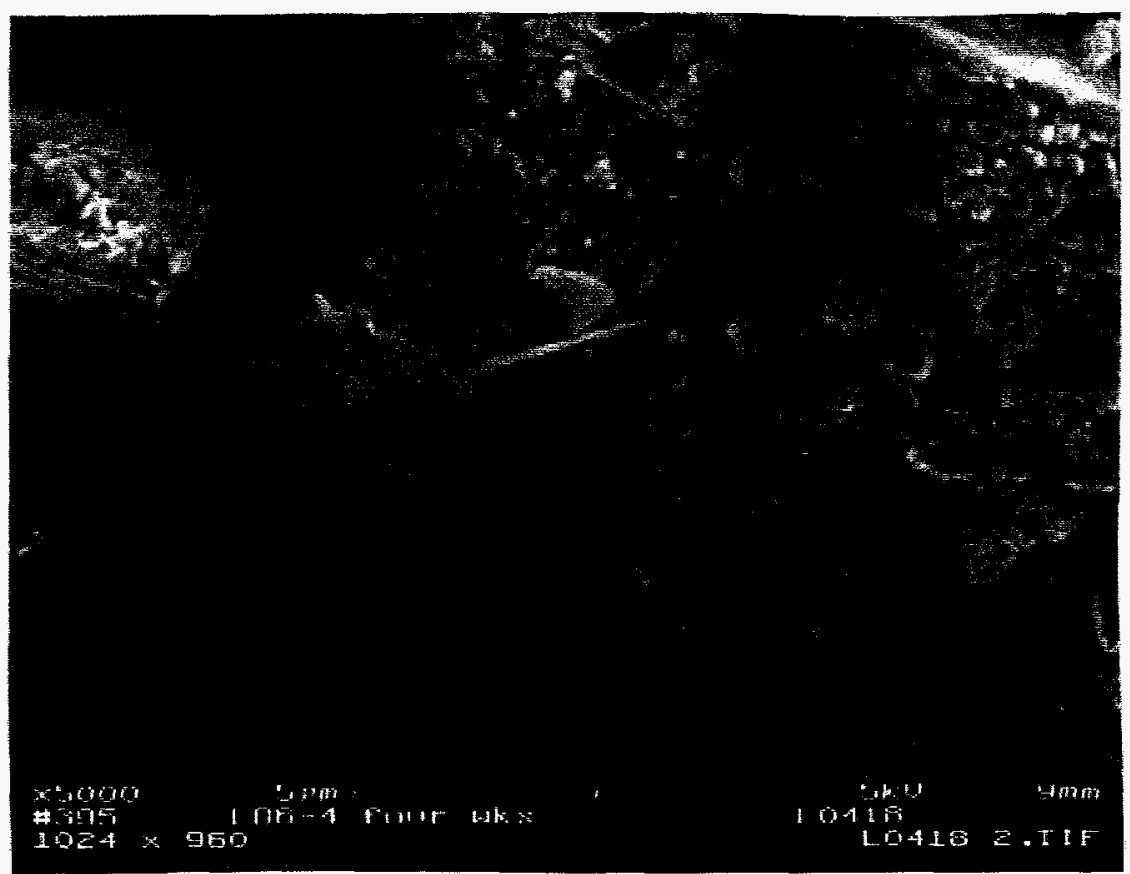

Figure 5. Scanning Electron Micrograph of Clusters of Prismatic Phillipsite Crystals Formed from Weathered LD6 Glass Particles

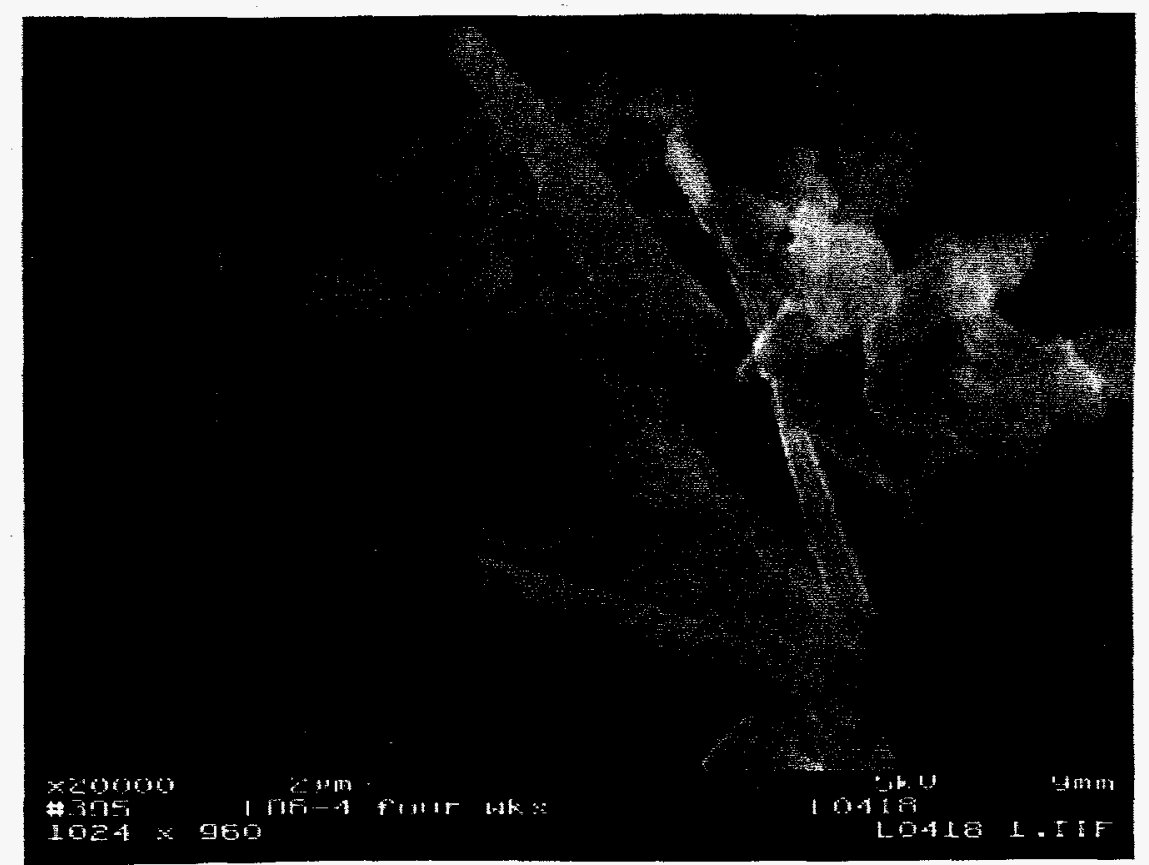

Figure 6. Higher Magnification Scanning Electron Micrograph of Phillipsite Crystals 
Table 3. Analysis of Phillipsite Crystals Formed from LD6 Glass

\begin{tabular}{|l|c|c|}
\hline \multicolumn{1}{|c|}{ Element (Oxide Basis) } & $\begin{array}{c}\text { Analysis 1 } \\
\text { (wt\%) }\end{array}$ & $\begin{array}{c}\text { Analysis 2 } \\
\text { (wt\%) }\end{array}$ \\
\hline \hline $\mathrm{Al}_{2} \mathrm{O}_{3}$ & 12.24 & 11.84 \\
\hline $\mathrm{CaO}$ & 4.24 & 7.22 \\
\hline $\mathrm{K}_{2} \mathrm{O}$ & 1.64 & 1.33 \\
\hline $\mathrm{Na}_{2} \mathrm{O}$ & 18.56 & 24.17 \\
\hline $\mathrm{SiO}_{2}$ & 63.21 & 55.15 \\
\hline
\end{tabular}

\subsubsection{Weathering Products of SRL202 Glass}

The XRD data indicated that at the end of the first week a crystalline secondary mineral had formed from weathering SRL202 glass (Figure 7). Subsequent analysis showed no significant changes in diffraction intensities, indicating that a major fraction of glass alteration reactions had taken place during the first week of weathering. Also, the broad, diffuse nature of the diffraction peaks indicated that the weathering product was a microcrystalline (submicron-size crystals) mineral. The diffraction data from weathered glass matched the standard diffraction data for nontronite, an iron-rich phyllosilicate mineral. Nontronite has a sheet-like structure with two sheets of silica tetrahedra sandwiching an octahedrally coordinated layer containing mainly iron (Figure 8). These structural units range from 9.5 to $10 \AA$ in thickness, and the interlayer space between adjacent structural units is occupied by exchangeable cations. A smaller fraction of exchangeable cations in this structure occupy ionized hydroxyl sites along the sheet edges.

Scanning electron micrographs of unreacted SRL202 glass showed particles $\sim 10$ to $20 \mu \mathrm{m}$ in average size, with typical conchoidally fractured surfaces and clear, smooth surfaces covered with smaller glass particles (Figure 9). In contrast, SEM examination of glass particles weathered for 4 weeks revealed roseate clusters of thin, sheet-like crystals of nontronite growing on matrices of highly weathered (corroded) glass (Figure 10). A highly magnified view of a cluster (Figure 11) indicates that these crystals are very thin $(\sim 0.05-\mu \mathrm{m})$ sheets and completely covered the glass surfaces. The morphology of these crystals reflect the sheet-like structure of a typical phyllosilicate mineral.

The chemical composition of nontronite crystals was measured using EDS. The elemental concentrations expressed on an oxide basis (Table 4) indicate that nontronite is silica and iron rich, which reflects the composition of the parent glass. Considering that 1 ) both iron and aluminum are conservative elements and that nontronite is a dioctahedral mineral (only two out of three octahedral coordination sites in the structure are filled mainly by a trivalent ion such as ferric iron) and 2) that nontronites have limited aluminum substitution for silicon in the tetrahedral layer (Newman and Brown 1987), an average unit cell formula for SRL202 glass-derived nontronite was estimated to be

$$
\left(\mathrm{Na}_{0.9} \mathrm{~K}_{0.4}\right)\left(\mathrm{Fe}_{2.0} \mathrm{Al}_{1.2} \mathrm{Mg}_{0.4} \mathrm{Mn}_{0.4}\right)\left(\mathrm{Si}_{7.5} \mathrm{Al}_{0.5}\right) \mathrm{O}_{20}(\mathrm{OH})_{4}
$$




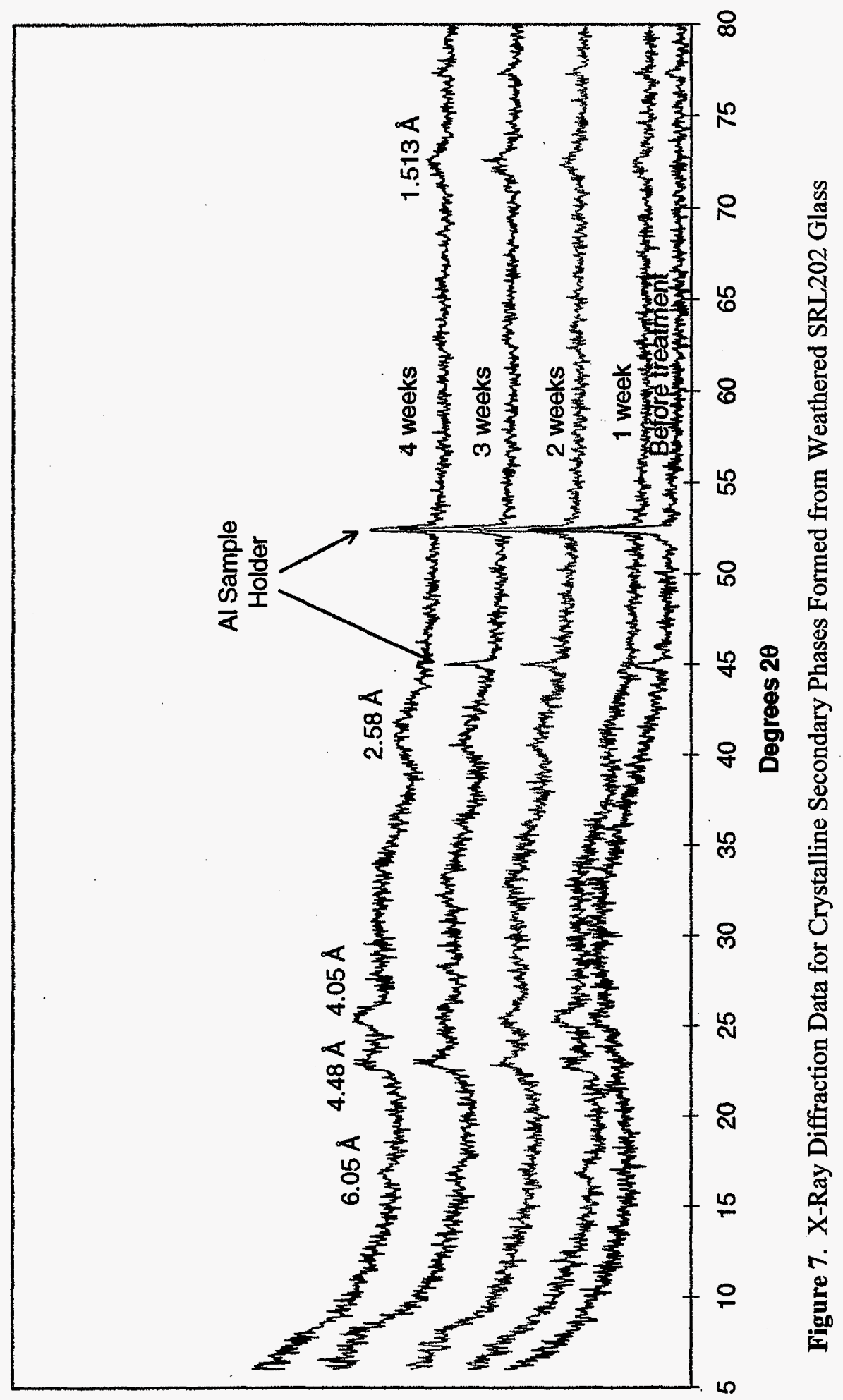




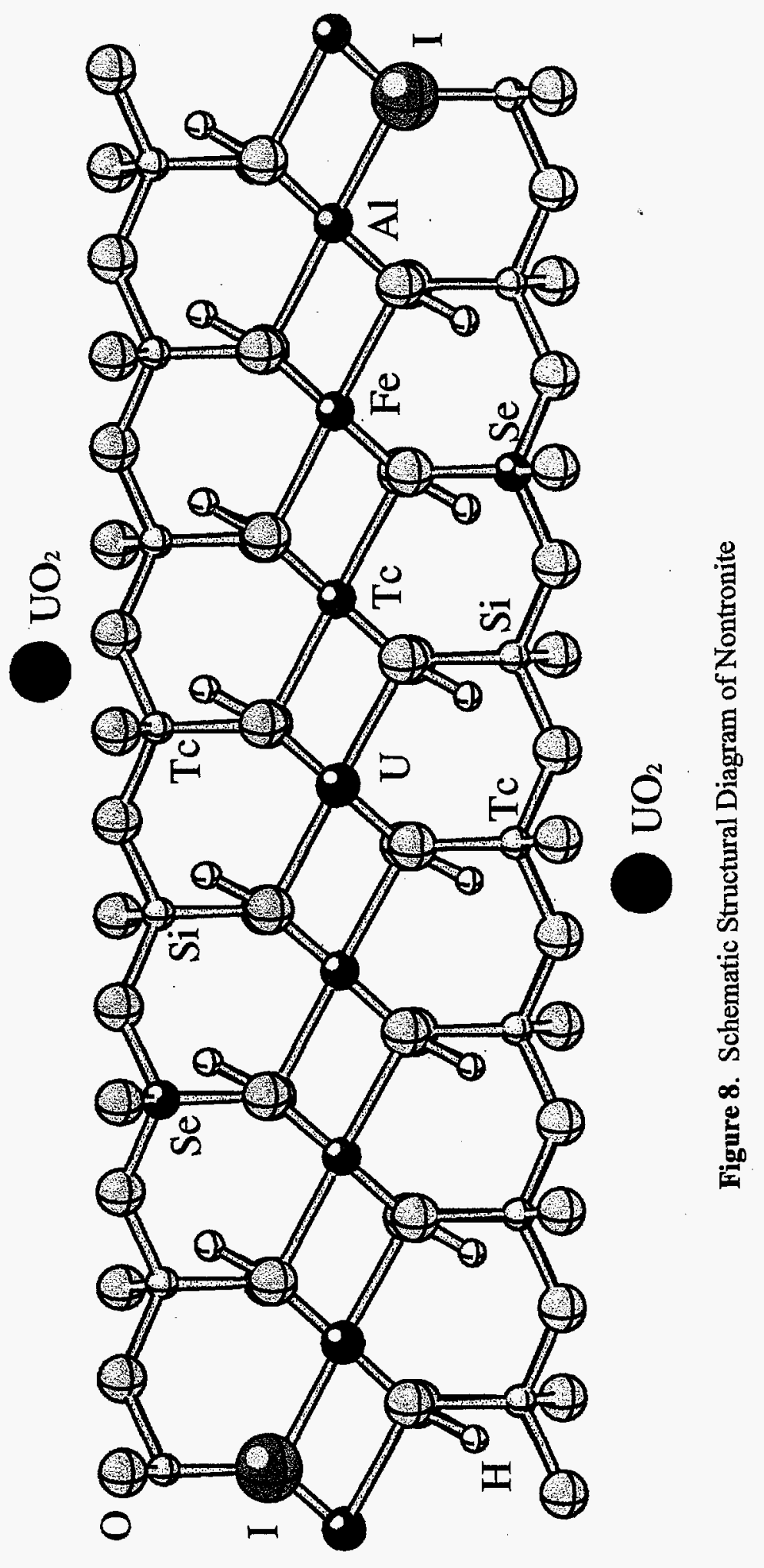




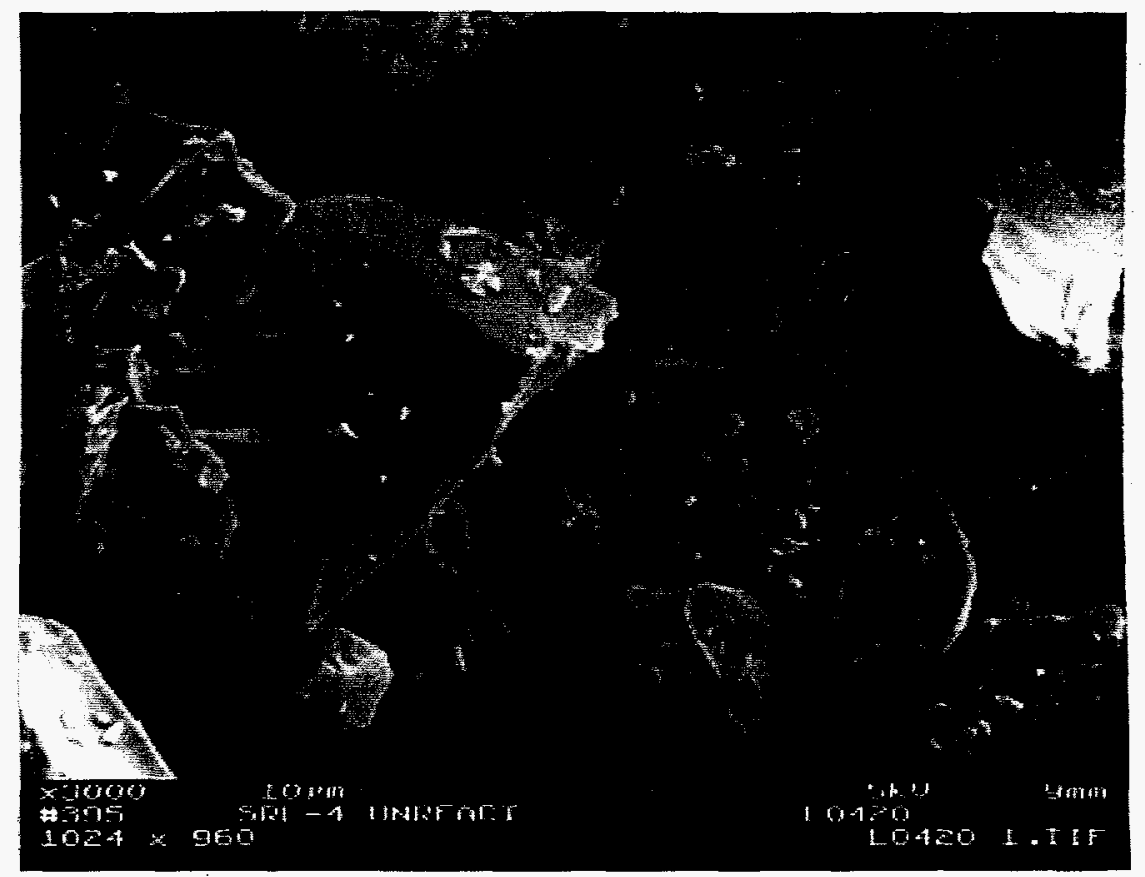

Figure 9. Scanning Electron Micrograph of Fresh SRL202 Glass Particles

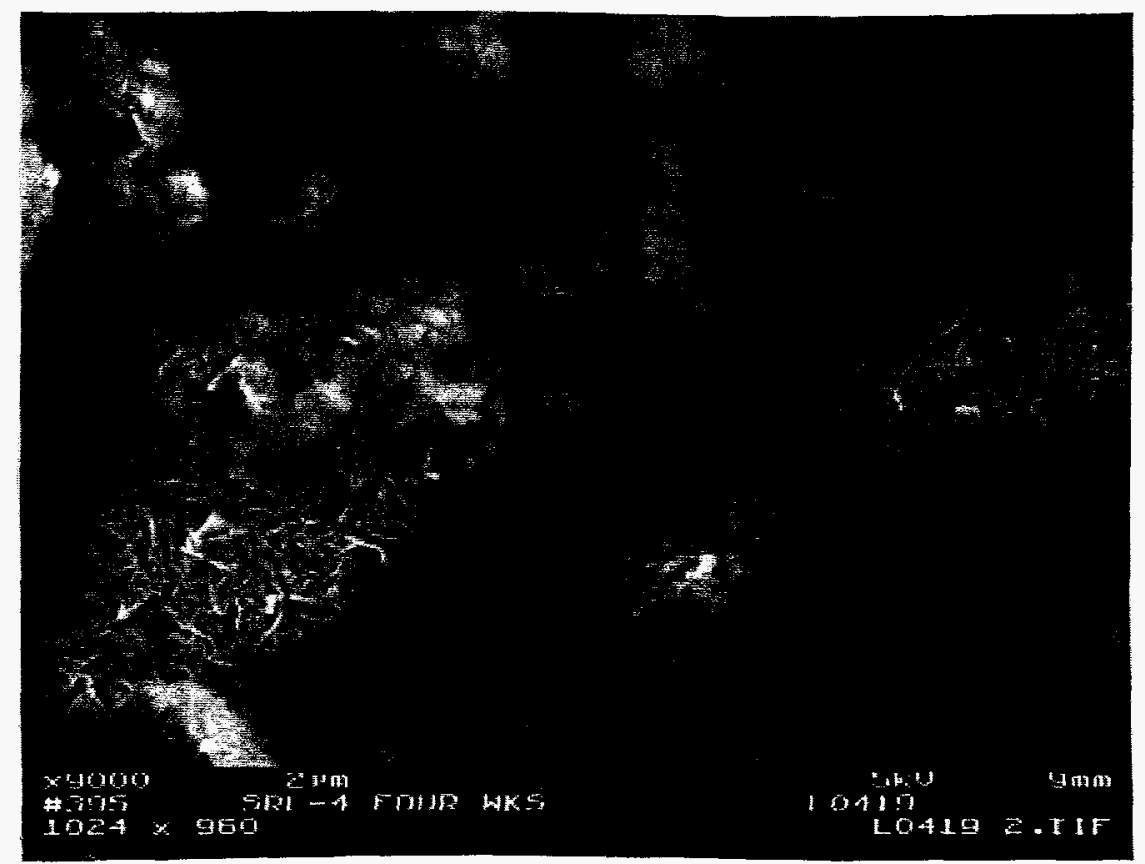

Figure 10. Scanning Electron Micrograph of Agglomerated Sheets of Nontronite Crystals Formed from Weathered SRL202 Glass Particles 


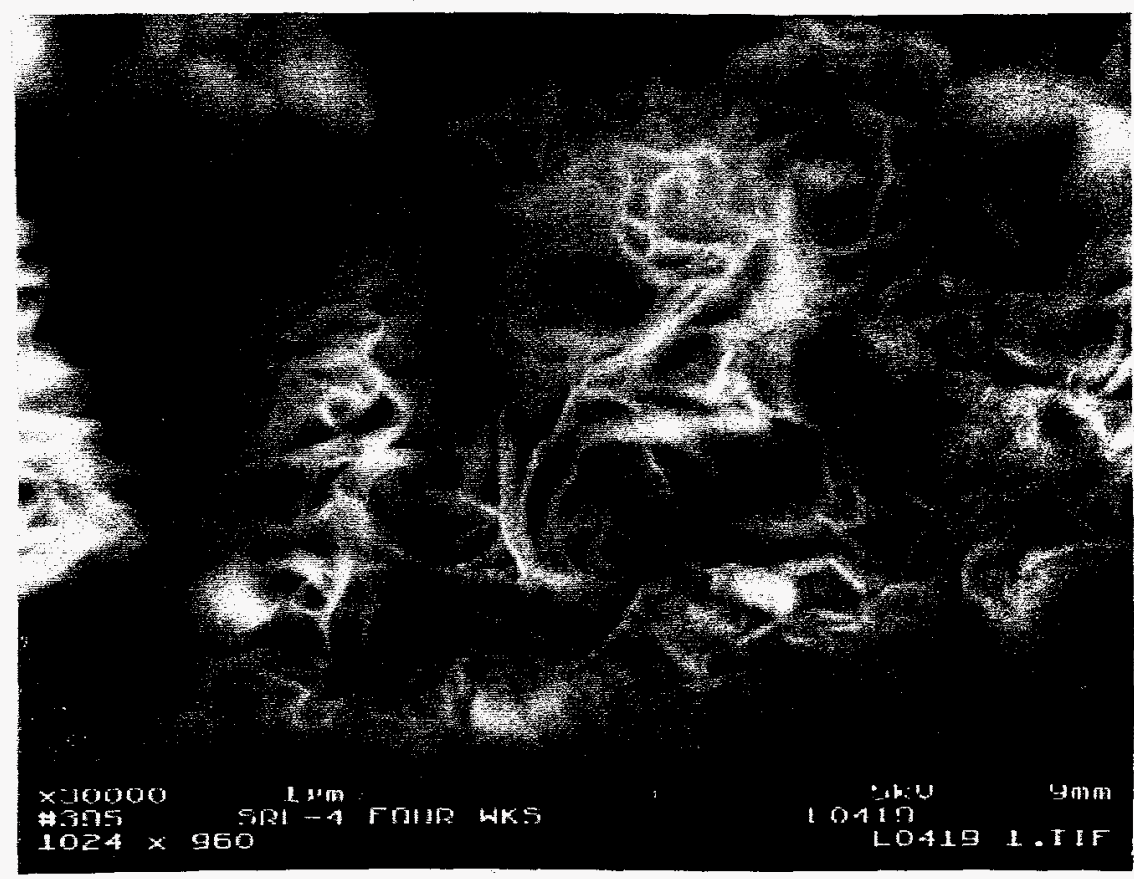

Figure 11. Higher Magnification Scanning Electron Micrograph of Nontronite Crystals

Table 4. Analysis of Nontronite Crystals Formed from SRL202 Glass

\begin{tabular}{||l|c|c|}
\hline Element (Oxide Basis) & $\begin{array}{c}\text { Analysis 1 } \\
(\mathrm{wt} \%)\end{array}$ & $\begin{array}{c}\text { Analysis 2 } \\
(\mathrm{wt} \%)\end{array}$ \\
\hline \hline $\mathrm{Al}_{2} \mathrm{O}_{3}$ & 6.00 & 5.77 \\
\hline $\mathrm{CaO}$ & 0.63 & 1.07 \\
\hline $\mathrm{Fe}_{2} \mathrm{O}_{3}$ & 9.53 & 12.05 \\
\hline $\mathrm{K}_{2} \mathrm{O}$ & 1.94 & 2.25 \\
\hline $\mathrm{MgO}$ & 3.14 & 1.54 \\
\hline $\mathrm{MnO}$ & 2.57 & 2.88 \\
\hline $\mathrm{Na} 2 \mathrm{O}$ & 3.56 & 4.32 \\
\hline $\mathrm{NiO}$ & 0.72 & 1.38 \\
\hline $\mathrm{SiO}_{2}$ & 70.77 & 66.40 \\
\hline
\end{tabular}

According to this estimated unit cell formula, $\sim 50 \%$ of the octahedrally coordinated sites in this nontronite are filled with ferric iron, and the principal exchangeable cation is sodium ( $70 \%$ of cationexchange capacity). The cation-exchange capacity of this mineral was calculated to be $\sim 1.56 \mathrm{meq} / \mathrm{g}$. 


\subsection{Radionuclide Sequestration Experiments}

\subsubsection{Radionuclide Substitutions in Phillipsite Phase}

The radionuclide-counting data indicated that $\sim 56 \%$ of ${ }^{75} \mathrm{Se}, \sim 85 \%$ of ${ }^{99} \mathrm{Tc}, \sim 49 \%$ of ${ }^{125} \mathrm{I}$, and $\sim 100 \%$ of ${ }^{238} \mathrm{U}$ activities were associated with the solid phases (Table 5). The activities associated with the solid phase would indicate that radionuclides initially present exclusively in solution phase had been incorporated into the secondary solid phases forming from the weathering glass.

Table 5. Radionuclide Fractions Associated with Phillipsite Mineral

\begin{tabular}{|l|c|c|c|c|}
\hline \multicolumn{1}{|c|}{ Activity Partitioning } & ${ }^{75} \mathrm{Se}$ & ${ }^{99} \mathrm{Tc}$ & ${ }^{125} \mathrm{I}$ & ${ }^{238} \mathrm{U}$ \\
\hline Total initial activity & $86.1 \mathrm{nCi}$ & $42.5 \mathrm{nCi}$ & $116.6 \mathrm{nCi}$ & $59.9 \mathrm{nCi}$ \\
\hline Total solid-phase activity & $48.3 \mathrm{nCi}$ & $36.2 \mathrm{nCi}^{(\mathrm{a})}$ & $56.9 \mathrm{nCi}$ & $59.9 \mathrm{nCi}^{(\mathrm{a})}$ \\
\hline Activity in phillipsite & $56 \%$ & $85 \%$ & $49 \%$ & $100 \%$ \\
\hline (a) Calculated on the basis of residual activity in solution. \\
\hline
\end{tabular}

Sequestration of radionuclides during glass weathering can occur as a result of either adsorption (exchange) and/or precipitation of secondary minerals. The formation of secondary minerals may involve precipitation of either a pure or a solid solution phase. For trace components such as radionuclides, the precipitation reactions involve incorporation in secondary minerals as solid solution phases. Based on extensive studies and literature surveys, Barrer (1982) identified a number of mechanisms that result in incorporation of various ionic components into zeolite structures.

- isomorphous (similar coordination-related ionic radii) substitution for tetrahedral Si and Al

- occupation of cation-exchange sites

- substitution of framework oxygen by other anionic species

- entrapment as salt molecules in zeolitic channels and cavities.

Each of these mechanisms was evaluated to assess the type of ionic incorporation that can account for the observed sequestration of ${ }^{75} \mathrm{Se},{ }^{99} \mathrm{Tc},{ }^{125} \mathrm{I}$, and ${ }^{238} \mathrm{U}$ in the phillipsite structure (Table 6).

The salt-molecule-entrapment mechanism requires very high concentrations of constituent ions. Because of the very low activities (trace concentrations) of radionuclides used in these experiments, it is unlikely that the radionuclides were incorporated into phillipsite in the form of salt molecules. Therefore, the evaluation matrix suggests that the most probable mechanisms for radionuclide incorporation in phillipsite are that ${ }^{75} \mathrm{Se}$ and ${ }^{99} \mathrm{Tc}$ substitute isomorphically in tetrahedral sites because their ionic radii are 
Table 6. Evaluation Matrix for Radionuclide Incorporation in Phillipsite Structure

\begin{tabular}{|c|c|c|c|c|}
\hline $\begin{array}{l}\text { Radio- } \\
\text { nuclide }\end{array}$ & $\begin{array}{c}\text { Isomorphous Substitution for } \\
\mathrm{Al} \text { and } \mathrm{Si} \text { in Tetrahedral } \\
\text { Coordination }\end{array}$ & $\begin{array}{l}\text { Occupation of Cation- } \\
\text { Exchange Site }\end{array}$ & $\begin{array}{c}\text { Framework } \\
\text { Oxygen } \\
\text { Substitution }\end{array}$ & $\begin{array}{c}\text { Salt Molecule } \\
\text { Entrapment }\end{array}$ \\
\hline${ }^{75} \mathrm{Se}$ & $\begin{array}{l}\text { Possible; ionic radius } \\
\text { compatible with } \mathrm{Si}\end{array}$ & $\begin{array}{l}\text { Oxyanion species }\left(\mathrm{SeO}_{4}{ }^{2-}\right) \\
\text { cannot occupy cationic site }\end{array}$ & $\begin{array}{l}\text { Oxyanion substi- } \\
\text { tutions not } \\
\text { observed }\end{array}$ & $\begin{array}{l}\text { Known to occur as } \\
\mathrm{Na}_{2} \mathrm{SeO}_{4} \text { molecule }\end{array}$ \\
\hline${ }^{99} \mathrm{Tc}$ & $\begin{array}{l}\text { Possible; ionic radius } \\
\text { compatible with } \mathrm{Al}\end{array}$ & $\begin{array}{l}\text { Oxyanion species }\left(\mathrm{TcO}_{4}^{-}\right) \\
\text {cannot occupy cationic site }\end{array}$ & $\begin{array}{l}\text { Oxyanion substi- } \\
\text { tutions not } \\
\text { observed }\end{array}$ & $\begin{array}{l}\text { Possible as alkali- } \\
\text { oxyanion salt }\end{array}$ \\
\hline${ }^{125} \mathrm{I}$ & $\begin{array}{l}\text { Anionic species; substitution } \\
\text { not possible }\end{array}$ & $\begin{array}{l}\text { Anionic species }\left(I^{\prime}\right) \text {; cannot } \\
\text { occupy cationic sites }\end{array}$ & $\begin{array}{l}\text { Halide substitu- } \\
\text { tion possible }\end{array}$ & $\begin{array}{l}\text { Known to occur as } \\
\mathrm{NaI} \text { and } \mathrm{KI} \text { molecules }\end{array}$ \\
\hline${ }^{238} \mathrm{U}$ & $\begin{array}{l}\text { Not possible; ionic radius } \\
\text { incompatible }\end{array}$ & $\begin{array}{l}\text { Oxycation species }\left(\mathrm{UO}_{2}{ }^{2+}\right) \\
\text { can occupy cation- } \\
\text { exchange site }\end{array}$ & $\begin{array}{l}\text { Oxycation substi- } \\
\text { tutions not } \\
\text { observed }\end{array}$ & Not observed \\
\hline
\end{tabular}

similar to $\mathrm{Si}$ and $\mathrm{Al},{ }^{125} \mathrm{I}$ substitutes for framework oxygen, and ${ }^{238} \mathrm{U}$ (as the $\mathrm{UO}_{2}{ }^{2+}$ species) occupies cation-exchange sites. The resulting unit cell formula of phillipsite as a solid solution of radionuclides can be represented as

$$
\left(\left\{\mathrm{UO}_{2}\right\}_{\mathrm{m}} \mathrm{Na}_{3.4} \mathrm{~K}_{0.6}\right)\left(\mathrm{Se}_{\mathrm{n}} \mathrm{Tc}_{\mathrm{p}} \mathrm{Al}_{4} \mathrm{Si}_{16}\right) \mathrm{I}_{q} \mathrm{O}_{20} \cdot 12 \mathrm{H}_{2} \mathrm{O}
$$

These substitutions in appropriate structural sites are indicated in a schematic structural diagram of phillipsite (see Figure 2).

\subsubsection{Radionuclide Substitutions in Nontronite Phase}

The radionuclide-counting data indicated that $\sim 28 \%$ of ${ }^{75} \mathrm{Se}, \sim 86 \%$ of ${ }^{99} \mathrm{Tc}, \sim 23 \%$ of ${ }^{125} \mathrm{I}$, and $\sim 100 \%$ of ${ }^{238} \mathrm{U}$ activities were associated with the solid phases (Table 7). The activities associated with the solid phase would indicate that radionuclides initially present exclusively in the solution phase had been incorporated into secondary solid phases formed from the weathering glass.

Table 7. Radionuclide Fractions Associated with Nontronite Mineral

\begin{tabular}{|l|c|c|c|c|}
\hline \multicolumn{1}{|c|}{ Activity Partitioning } & ${ }^{75} \mathrm{Se}$ & ${ }^{99} \mathrm{Tc}$ & ${ }^{125} \mathrm{I}$ & ${ }^{238} \mathrm{U}$ \\
\hline \hline Total initial activity & $86.1 \mathrm{nCi}$ & $42.5 \mathrm{nCi}$ & $116.6 \mathrm{nCi}$ & $59.9 \mathrm{nCi}$ \\
\hline Total solid-phase activity & $24.5 \mathrm{nCi}$ & $36.2 \mathrm{nCi}^{(\mathrm{a})}$ & $26.5 \mathrm{nCi}$ & $59.9 \mathrm{nCi}^{(\mathrm{a})}$ \\
\hline Activity in phillipsite & $28 \%$ & $86 \%$ & $23 \%$ & $100 \%$ \\
\hline (a) Calculated on the basis of residual activity in solution. & & \\
\hline
\end{tabular}


As previously indicated, such sequestration of radionuclides can occur as the result of either adsorption (exchange) and/or precipitation of secondary minerals. The mechanisms of ionic incorporation into structures of phyllosilicate minerals such as nontronite are very similar to the mechanisms observed for framework silicates such as zeolites, except salt molecule entrapment is not known to occur in phyllosilicate structures.

Therefore, three potential mechanisms (isomorphous substitution, cation exchange, and framework oxygen substitution) were evaluated to identify the type of ionic incorporation that can account for the observed sequestration of ${ }^{75} \mathrm{Se},{ }^{99} \mathrm{Tc},{ }^{125} \mathrm{I}$, and ${ }^{238} \mathrm{U}$ in nontronite structure (Table 8).

Table 8. Evaluation Matrix for Radionuclide Incorporation in Nontronite Structure

\begin{tabular}{|l|l|l|l||}
\hline Radionuclide & $\begin{array}{l}\text { Isomorphous Substitution for } \mathrm{Al} \text { and } \\
\text { Si in Tetrahedral and } \mathrm{Fe}(\mathrm{III}) \text { and } \mathrm{Al} \\
\text { in Octahedral Coordination }\end{array}$ & \multicolumn{1}{|c|}{$\begin{array}{c}\text { Occupation of Cation- } \\
\text { Exchange Site }\end{array}$} & \multicolumn{1}{|c|}{$\begin{array}{c}\text { Framework Oxygen } \\
\text { Substitution }\end{array}$} \\
\hline${ }^{75} \mathrm{Se}$ & $\begin{array}{l}\text { Possible in tetrahedral sites; ionic } \\
\text { radius compatible with } \mathrm{Si}\end{array}$ & $\begin{array}{l}\text { Oxyanion species }\left(\mathrm{SeO}_{4}{ }^{2-}\right) ; \\
\text { cannot occupy cationic site }\end{array}$ & $\begin{array}{l}\text { Oxyanion substitutions not } \\
\text { observed }\end{array}$ \\
\hline${ }^{99} \mathrm{Tc}$ & $\begin{array}{l}\text { Possible; ionic radii compatible for } \\
\text { both tetrahedral and octahedral sites }\end{array}$ & $\begin{array}{l}\text { Oxyanion species }\left(\mathrm{TcO}_{4}{ }^{-}\right) ; \\
\text {cannot occupy cationic site }\end{array}$ & $\begin{array}{l}\text { Oxyanion substitutions not } \\
\text { observed }\end{array}$ \\
\hline${ }^{125 \mathrm{I}}$ & $\begin{array}{l}\text { Anionic species; substitution not } \\
\text { possible }\end{array}$ & $\begin{array}{l}\text { Anionic species }(\mathrm{I}) ; \text { cannot } \\
\text { occupy cationic sites }\end{array}$ & Halide substitution possible \\
\hline${ }^{238} \mathrm{U}$ & $\begin{array}{l}\text { Possible; ionic radius compatible for } \\
\text { octahedral substitution }\end{array}$ & $\begin{array}{l}\text { Oxycation species }\left(\mathrm{UO}_{2}{ }^{2+}\right) ; \\
\text { can occupy cation-exchange } \\
\text { site }\end{array}$ & $\begin{array}{l}\text { Oxycation substitutions not } \\
\text { observed }\end{array}$ \\
\hline
\end{tabular}

The matrix in Table 8 suggests that the most probable mechanisms of radionuclide incorporation in nontronite are as follows:

- isomorphous substitution of ${ }^{75} \mathrm{Se}$ for $\mathrm{Si}$ in tetrahedral sites

- isomorphous substitution of ${ }^{99} \mathrm{Tc}$ for $\mathrm{Al}$ in tetrahedral sites and/or for $\mathrm{Fe}$ and $\mathrm{Al}$ in octahedral sites

- framework oxygen replaced by ${ }^{125} \mathrm{I}$ anions

- isomorphous substitutions of ${ }^{238} \mathrm{U}$ for $\mathrm{Fe}$ and $\mathrm{Al}$ in octahedral sites and/or occupation of cationexchange sites (interlayer and edge sites).

The resulting unit cell formula of nontronite as a solid solution of radionuclides can be represented as

$$
\left(\left\{\mathrm{UO}_{2}\right\}_{\mathrm{m}} \mathrm{Na}_{0.9} \mathrm{~K}_{0.4}\right)\left(\mathrm{Tc}_{\mathrm{n}} \mathrm{U}_{\mathrm{p}} \mathrm{Fe}_{2.0} \mathrm{Al}_{1.2} \mathrm{Mg}_{0.4} \mathrm{Mn}_{0.4}\right)\left(\mathrm{Se}_{\mathrm{q}} \mathrm{Si}_{7.5} \mathrm{Tc}_{\mathrm{s}} \mathrm{Al}_{0.5}\right) \mathrm{I}_{\mathrm{t}} \mathrm{O}_{20}(\mathrm{OH})_{4}
$$

These substitutions in appropriate structural sites are indicated in a schematic structure of nontronite (see Figure 8). 


\subsection{Conclusions}

Weathering of a sodium aluminosilicate glass (LD60) at $90^{\circ} \mathrm{C}$ with minor amounts of calcium, potassium, and boron resulted in the formation of a zeolite mineral, phillipsite, with an approximate composition of

$$
\left(\mathrm{Na}_{3.4} \mathrm{~K}_{0.6}\right)\left(\mathrm{Al}_{4} \mathrm{Si}_{16}\right) \mathrm{O}_{20} \cdot 12 \mathrm{H}_{2} \mathrm{O} \text {. }
$$

SEM observations of LD6 glass stored at room temperature indicated the phillipsite formation can occur under ambient conditions. In contrast, weathering of an alkali (lithium, sodium, and potassium) iron borosilicate glass (SRL202) at $90^{\circ} \mathrm{C}$ produced a phyllosilicate mineral, nontronite, with an approximate composition of

$$
\left(\mathrm{Na}_{0.9} \mathrm{~K}_{0.4}\right)\left(\mathrm{Fe}_{2.0} \mathrm{Al}_{1.2} \mathrm{Mg}_{0.4} \mathrm{Mn}_{0.4}\right)\left(\mathrm{Si}_{7.5} \mathrm{Al}_{0.5}\right) \mathrm{O}_{20}(\mathrm{OH})_{4}
$$

The weathering experiment conducted at $90^{\circ} \mathrm{C}$ on LD6 glass with radionuclide-spiked Hanford Site groundwater indicated that substantial fractions of the total activities were retained in the phillipsite structure: $\sim 56 \%$ of ${ }^{75} \mathrm{Se}, \sim 85 \%$ of ${ }^{99} \mathrm{Tc}, \sim 49 \%$ of ${ }^{125} \mathrm{I}$, and $\sim 100 \%$ of ${ }^{238} \mathrm{U}$. The most probable mechanisms of radionuclide incorporation in phillipsite were assessed to be the isomorphous substitution of ${ }^{75} \mathrm{Se}$ and ${ }^{99} \mathrm{Tc}$ for $\mathrm{Si}$ and $\mathrm{Al}$ in tetrahedral sites, substitution of ${ }^{125} \mathrm{I}$ for framework oxygen, and cation-exchange site occupation of ${ }^{238} \mathrm{U}$ (as the $\mathrm{UO}_{2}{ }^{2+}$ species). The resulting unit cell formula of phillipsite as a solid solution of radionuclides was estimated to be

$$
\left(\left\{\mathrm{UO}_{2}\right\}_{\mathrm{m}} \mathrm{Na}_{3.4} \mathrm{~K}_{0.6}\right)\left(\mathrm{Se}_{\mathrm{n}} \mathrm{Tc}_{\mathrm{p}} \mathrm{Al}_{4} \mathrm{Si}_{16}\right) \mathrm{I}_{q} \mathrm{O}_{20} \cdot 12 \mathrm{H}_{2} \mathrm{O}
$$

Weathering experiments conducted at $90^{\circ} \mathrm{C}$ on SRL202 glass with radionuclide-spiked Hanford Site groundwater indicated that significant fractions of the total activities were retained in the nontronite structure: $\sim 28 \%$ of ${ }^{75} \mathrm{Se}, \sim 86 \%$ of ${ }^{99} \mathrm{Tc}, \sim 23 \%$ of ${ }^{125} \mathrm{I}$, and $\sim 100 \%$ of ${ }^{238} \mathrm{U}$. The most probable mechanisms of radionuclide incorporation in nontronite were assessed to be the isomorphous substitutions of ${ }^{75} \mathrm{Se}$ for $\mathrm{Si}$ in tetrahedral sites and of ${ }^{99} \mathrm{Tc}$ for $\mathrm{Al}$ in tetrahedral sites and/or for $\mathrm{Fe}$ and $\mathrm{Al}$ in octahedral sites, substitution of ${ }^{125} \mathrm{I}$ for framework oxygen, and isomorphous substitutions of ${ }^{238} \mathrm{U}$ for $\mathrm{Fe}$ and $\mathrm{Al}$ in octahedral sites and/or occupation of cation-exchange sites (interlayer and edge sites). The resulting unit cell formula of nontronite as a solid solution of radionuclides was estimated to be

$$
\left(\left\{\mathrm{UO}_{2}\right\}_{\mathrm{m}} \mathrm{Na}_{0.9} \mathrm{~K}_{0.4}\right)\left(\mathrm{Tc}_{\mathrm{n}} \mathrm{U}_{\mathrm{p}} \mathrm{Fe}_{2.0} \mathrm{Al}_{1.2} \mathrm{Mg}_{0.4} \mathrm{Mn}_{0.4}\right)\left(\mathrm{Se}_{\mathrm{q}} \mathrm{Si}_{7.5} \mathrm{Tc}_{\mathrm{r}} \mathrm{Al}_{0.5}\right) \mathrm{I}_{\mathrm{s}} \mathrm{O}_{20}(\mathrm{OH})_{4}
$$

These results have some important implications regarding the radionuclide mobilization aspects of ILAW performance assessment. 
- Weathering of waste glasses at $90^{\circ} \mathrm{C}$ results in the formation of crystalline secondary phases such as zeolites and smectites. The types of secondary minerals that form depend on the chemical compositions of weathering parent waste glasses. Formation of these secondary minerals can also occur under ambient weathering conditions.

- Significant fractions of radionuclides from weathering waste glasses can be sequestered by the secondary zeolitic and smectitic minerals that form relatively rapidly during the weathering process.

- The radionuclides sequestered in secondary zeolitic and smectitic minerals exist in the form of solid solutions; therefore, the rate of mobilization of radionuclides would be controlled by the kinetics of dissolution of these secondary crystalline minerals.

- The upper limits of radionuclide activities released from secondary crystalline minerals can be predicted from the equilibrium solubilities of secondary crystalline solid phases.

Additional studies are needed to confirm these results and to develop an improved understanding of mechanisms of sequestration and attenuated release of radionuclides. Improved understanding of this phenomenon is expected to help refine certain aspects of the radionuclide mobilization part of the ILAW performance assessment. These additional studies include the following:

- types of secondary minerals that form from a range of specific glass compositions that would be used to stabilize nuclear wastes

- range of radionuclide substitutions that occur in secondary crystalline minerals

- kinetics of dissolution of radionuclide-bearing secondary crystalline phases under environmental conditions

- determination of upper limits of radionuclide activity in aqueous phase from studies of equilibrium solubilities of radionuclide-bearing secondary crystalline phases.

\subsection{References}

Barrer RM. 1982. Hydrothermal chemistry of zeolites. Academic Press, New York.

Breck DW. 1974. Zeolite molecular sieves. John Wiley and Sons, New York.

Caurel J, D Beaufort, and EY Vernaz. 1988. "Mineral phase identification along two profiles from LWR French reference glass: Use of an x-ray position sensitive detector." Material Research Society Symposium Proceedings, v. 112, pp. 663-672, Material Research Society, Pittsburgh, Pennsylvania. 
Collella C, R Aiello, and C Porcelli. 1978. "Hydration as an early stage in the zeolitization of natural glass." Natural Zeolites, LB Sand and FA Mumpton (eds.), Pergamon Press, Oxford, pp. 345-350.

Dyer A. 1988. An introduction to zeolite molecular sieves. John Wiley and Sons, New York.

Ebert WL, and SW Tam. 1997. "Dissolution rates of DWPF glasses from long-term PCT." Scientific Basis for Nuclear Waste Management XX, WJ Gray and I Triay (eds.), v. 465, pp. 149-156, Material Research Society, Pittsburgh, Pennsylvania.

Fortner JA, SF Wolf, EC Buck, CJ Mertz, and JK Bates. 1997. "Solution-borne colloids from drip tests using actinide-doped and fully-radioactive waste glasses." Scientific Basis for Nuclear Waste Management XX, WJ Gray and I Triay (eds.), v. 465, pp. 165-172, Material Research Society, Pittsburgh, Pennsylvania.

Gottardi G, and E Galli. 1985. Natural zeolites. Springer-Verlag, Berlin.

Haaker R, G Malow, and P Offerman. 1985. "The effects of phase formation on glass leaching." Material Research Society Symposium Proceedings, v. 44, pp. 121-128, Material Research Society, Pittsburgh, Pennsylvania.

Holler $\mathrm{H}$, and $\mathrm{U}$ Wirsching. 1978. Experiments on the formation of zeolites by hydrothermal alteration of volcanic glasses." Natural Zeolites, LB Sand and FA Mumpton (eds.), Pergamon Press, Oxford, pp. 329-336.

Luo JS, WL Ebert, JJ Mazer, and JK Bates. 1997. "Simulation of natural corrosion of vapor hydration test: Seven year results. Scientific Basis for Nuclear Waste Management XX, WJ Gray and I Triay (eds.), v. 465, pp. 157-163, Material Research Society, Pittsburgh, Pennsylvania.

Lutze W, R Muller, and W Montserrat. 1988. "Chemical corrosion of COGEMA glass R7T7 in high saline brines." Material Research Society Symposium Proceedings, v. 112, pp. 575-584, Material Research Society, Pittsburgh, Pennsylvania.

Mann FM, RJ Puigh, II, PD Rittmann, NW Kline, JA Voogd, Y Chen, CR Eiholzer, CT Kincaid, BP McGrail, AH Lu, GF Williamson, NR Brown, and PE LaMont. 1998. Hanford Immobilized LowActivity Tank Waste Performance Assessment. DOE/RL-97-69, Rev. 0, U.S. Department of Energy, Richland Operations Office, Richland, Washington.

McGrail BP, WL Ebert, AJ Bakel, and DK Peeler. 1997a. "Measurement of kinetic rate law parameters on a Na-Ca-Al borosilicate glass for low-activity waste. Journal of Nuclear Material 249:175-179.

McGrail BP, PF Martin, and CW Lindenmeier. 1997b. "Accelerated testing of waste forma using a novel pressurized unsaturated flow (PUF) method." Scientific Basis for Nuclear Waste Management XX, WJ Gray and I Triay (eds.), v. 465, pp. 253-260, Material Research Society, Pittsburgh, Pennsylvania. 
McGrail BP, WL Ebert, DH Bacon, and DM Strachan. 1998. A strategy to conduct an analysis of the long-term performance of low-activity waste glass in a shallow subsurface disposal system at Hanford. PNNL-11834, Pacific Northwest National Laboratory, Richland, Washington.

Newman ACD, and G Brown. 1987. "The chemical constitution of clays." Chemistry of Clays and Clay Minerals, ACD Brown (ed.), pp. 1-128, John Wiley and Sons, New York.

Van Iseghem PP, W Timmermans, and R De Batist. 1985. "Parametric study of the corrosion behavior in static distilled water of simulated European reference high-level waste glasses." Material Research Society Symposium Proceedings, v. 44, pp. 55-62, Material Research Society, Pittsburgh, Pennsylvania.

Van Iseghem PP, and B Grambow. 1988. "The long-term corrosion and modelling of two simulated Belgian reference high-level waste glasses." Material Research Society Symposium Proceedings, v. 112, pp. 631-639, Material Research Society, Pittsburgh, Pennsylvania. 


\section{Distribution}

No. of

Copies

\section{OFFSITE}

3 D. I. Kaplan

Westinghouse Savannah River Company

773-A Room B121

Aiken, SC 29802

ONSITE

5 DOE Richland Operations Office

N. R. Brown

M. J. Furman

P. E. LaMont

J. A. Poppiti

K. M.Thompson

Fluor Daniel Hanford, Inc.

J. D. Williams

5 Fluor Daniel Northwest, Inc.

F. M. Mann (4)

R. Khaleel
No. of

Copies

4 Lockheed Martin Hanford Corporation
E. A. Fredenburg
R1-04
D. A. Myers
R1-04
J. A. Voogd
S4-45
R. W. Root
R2-53

Waste Management Federal Services, Inc.

M. I. Wood

H6-06

$\mathrm{A} 0-12$

$\mathrm{HO}-12$

$\mathrm{H} 0-12$

S7-54

$\mathrm{H} 0-12$

30 Pacific Northwest National Laboratory

M. J. Fayer

K9-33

V. G. Johnson

K6-96

C. T. Kincaid

K9-33

V. L. LeGore

K6-81

S. V: Mattigod (5)

K6-81

B. P. McGrail (5)

K6-81

R. D. Orr

K6-81

H. T. Schaef

K6-81

R. J. Serne (5)

K6-81

R. M. Smith

K6-96

J. S. Young

K8-96

Information Release Office (7)

K1-06 